Journal of Advanced Research in Business

and Management Studies

\title{
Level of Shareholders Activism among Malaysian listed companies-An overview
}

\author{
Mohd Shazwan Mohd Ariffn ${ }^{1,}{ }^{*}$, Wan Nordin Wan-Hussin ${ }^{1}$, Siti Seri Delima Abdul Malak ${ }^{2}$ \\ Othman Yeop Abdullah Graduate School of Business, Universiti Utara Malaysia, Malaysia \\ 2 Tunku Intan Safinaz School of Accountancy, Universiti Utara Malaysia, Malaysia
}

\section{ABSTRACT}

The shareholder's activism attention rapidly increased over the year. Sapura Energy' Berhad scenario an example of the shareholder's awareness in Malaysian listed companies. Specifically, the shareholders must exercise their right to attend and vote at the general meeting under Companies Act 2016. Guided by the Outcome of the Meeting of Bursa Malaysia Securities Berhad, a total of 184 firms was chosen for the sample of this paper. The indicators for shareholder's activism was measured by two option (a) number of agenda of the resolution and (b) number of dissatisfaction or against the resolution. Meanwhile, MSWG acted as the pivotal bodies to safeguard the minority shareholders. From findings, even though the results show that both option did not bring any significant impact toward level of shareholders' activism however the awareness toward shareholder's activism rapidly increase in Malaysia. Thus, this paper critically discusses the contribution, limitation and future studies can be done to improve level of shareholder's activism among Malaysia listed companies.

Keywords:

Meeting, MSWG, shareholders activism, firms, Malaysia

Copyright @ 2020 PENERBIT AKADEMIA BARU - All rights reserved

\section{Introduction}

Beginning on January 31, 2017, Malaysia adopted the new Companies Act 2016 to replace the existing Companies Act 1965 with the intention to promote better governance and attract more investors doing business in Malaysia [1]. Generally, one of the platforms for the dialogue between the management and the firms is through the general meeting. In Malaysia, the listed firms specifically required to convene its general meeting once in every calendar year to transact ordinary business as stated by the Companies Act 2016 pursuant to Section 143(1) [1].

Section 143 (1) provides fundamental business items that are usually discussed at the Annual General Meeting (AGM). Among the main items focused by this section consist of (a) to receive the Audited Financial Statements (AFS), (b) to re-elect directors to retire by rotation, (c) to approve payment of the directors' fees and (d) to appoint reappointment of the Auditors. In order to carried the resolution, it required the approval of the shareholders which is the main topic of this paper.

\footnotetext{
* Corresponding author.

E-mail address: mohd_shazwan1@oyagsb.uum.edu.my
} 


\subsection{Background of the Study}

One of the indicator to measure the effectiveness of the shareholders is through the right and power uphold by the shareholders. Thus, shareholders will ensure that their right to attend the general meeting and vote on the certain resolution can be utilise during the meeting. Hence, the aggressive shareholders demand for more profit maximization meanwhile certain shareholders concern on protect their interest as the ownership of the companies. The shareholder's activism prevails a voting process either vote for or against the resolution. Even though, generally almost shareholders will vote for the resolution however trends on previous general meeting such as Sapura Energy's Berhad annual general meeting in 2018 shows the dissatisfaction among shareholders toward Tan Sri Shahril excessive remunerations even Sapura Energy's Berhad facing loss of profit cause serious awareness of shareholders' activism. Even though this is among the rare situation however this scenario an evidence of the level shareholder's activism among Malaysia listed companies $^{1}$.

\subsection{An Overview}

General meeting plays vital roles as a platform for the investors to raise their concern on the company business. Through AGM, both the management and the ownership can meet and discuss on the companies' direction. Legally, any general meeting held by the public companies must be recorded and minute as proof of evidence documentation specified under Section 343(1) of the Act [1]. Besides, through AGM minutes, the documentation captures all the important information such as attendance list of the meeting, agenda discussed, voting results and matters arising discuss during the general meeting including frequent questions and answers raised by the shareholders.

There a mixed definition of shareholders. From Bursa Malaysia Listing Requirements itself, shareholders can be divided into minority shareholders and major shareholders. Most of the major shareholder's act as the controlling power and minority shareholders tend to be less protected. Controlling shareholders can be defined as any person or a group that exercise the control power more than 33 percent from voting shares in a companies [2]. Meanwhile, a substantial shareholder happened once (a) in case if a person, has one or more voting share in the companies with number or aggregate share is not less than five per centum of the total voting shares or (b) in case if a company, two or more class of share or the number of aggregate share is not less than five per centum of the total voting shares as stipulated under Section 136(1) of the Act [1].

To compare, major shareholders or dominant shareholders have an interest in one or more shares of a corporation either by (a) 10 percent of total number of share vote or five percent or more of the total number of share vote of the corporation [2].

The remaining part of this paper is structured as follows: first, the literature review on the shareholder's activism critically discussed in this paper. Second, the relevance research framework was fully discussed. Next, using appropriative methodology techniques, analysis toward level of shareholder's activism in Malaysian listed companies was reported. Finally, the paper remarks with the conclusion and highlighted the importance of the level shareholder's activism especially among Malaysia listed companies.

\footnotetext{
1 Retrieved from: https://www.thestar.com.my/business/business-news/2018/07/19/shahril-survives-ouster-move-atagm/ dated July 19, 2018.
} 


\section{Literature Review}

This paper focuses on the phenomenon of shareholder's activism in Malaysian listed companies that had been debated over decades. However, it was quite a surprise that not many studies had been focusing on shareholders' activism such as institutional investors it relation to voluntary disclosure especially for emerging countries such as Malaysia [11]; [12]. In fact, most of active shareholders are dominated by the majority shareholders that suppress the right of minority shareholders in Malaysia [22]. The existence of the Minority Shareholders Watch Group (MSWG) purposely to protect the interest of minority shareholders from domination of majority shareholders [23]. In fact, De Jong [13] reported that majority shareholders tend to monopolise the decision making at the general meeting with large share hold either by an individual or institutional investors that most likely tend to influence the agency theory and maximize shareholder's wealth [14].

To retried, the agency theory existed due to the conflict between the management (directorship) and the ownership (shareholders) that cause dispute between two parties [24]. More importantly, the conflict between the parties lead to the separation of power between majority and minority shareholders. As such, the more voting share uphold by the person or a corporation indicate their power and right toward the companies they invest. This statement also agreed by Van der Elst (2012), cited in [3] pointed out that shareholders can be said as the owners of the company that contribute in terms of investment for running of the business and stressed that important of shareholders is indisputable. Hence, shareholders possess ultimate power and as the final makers of the meeting even though not directly controlled management of the firms. Besides, shareholders can be categorised into individual shareholders, corporate shareholders, institutional shareholders and nonprofit organisation such as Employees Provident Fund (EPF), Armed Forces Fund Board (LTAT), National Capital Berhad (PNB) and Social Security Organisation (SOCSO) [25].

Salim et. al., [4] argued that shareholders have the right to attend and vote in firms' general meeting. In cases where shareholders could not attend the meeting, they have the right to appoint a proxy to attend and vote on behalf of them. In fact, a proxy has the same right as ordinary shareholders to attend, speak and vote at the general meeting except he or she is not entitled to vote by show of hands (Section 149(1) of the Companies Act 1965 [1]). However, proxy role is not reliable with newly Companies Act 2016. The update Bursa Malaysia Listing Requirements 7.19 clearly specified the voting right of proxy [2].

Meanwhile, activism refers to the policy or action of using vigorous campaigning to bring about political or social change [5]. So far, Konrath et. al., [6], cited by Klein and Zur, 2009) the more active shareholders will lead to more decision making in the general meeting. The research to date has the tendency to focus on shareholders rather than activism that leads toward shareholders' activism. One of the main reason because the shareholders right and power that influence the activism to occur especially during the AGM. In this paper context, shareholder's activism can be defined as the participation of the shareholders in exercising their power and vote during the general meetings. Moreover, to indicate level of the shareholder's activism among Malaysian listed companies, the shareholder's activism will be review based on the monitoring system and control mechanism adopted by the governance structure [7-8].

This paper confirms prior studies that the management relies on the shareholder's commitment especially during the AGM in determining the corporate policy and business venture [9]. As such, once companies increase vulnerability, shareholders become actively participate in the company's decision making which become central agenda of this paper $[6,11]$. Overall, shareholder's activism can be seeming from the person and the corporation bodies, hence this paper attempts to examine the level of shareholder's activism from Malaysia perspective. As a multi-racial and multi ethnicity, 
most of the listed companies comprised of non-Malaysia and Malaysia shareholders. Malaysia shareholders can be divide either Malay, Chinese, Indian, Bumiputera or native citizen. This uniqueness leads this paper valuable for the shareholder's activism studies [26].

So far, few studies that focused on the shareholder activism from the perspective number of voting either the resolution are passed in favour or against by the shareholders [3]. Prior studies, however, have neglected to demonstrate the relationship between a number of voting and shareholder's participation at the general meeting of the five countries in ASEAN $[15,16]$. Meanwhile, for instance, the research to date has shown that in the Swedish general meeting, there is an impact of shareholders activism toward the level of awareness on the participate at the general meetings $[17,18]$.

\section{Methodology}

Companies will conduct its AGM either on June or December prior to its financial year ended. Generally, each financial year comprise of 500 listed companies. Using the Statistical Package for the Social Sciences (SPSS) software version 24.0 and secondary data from the company's website and Bursa Announcement(s), a total of 184 firms have been selected as a sample of the paper. Using generalisation, all listed companies prior to financial year ended December 31, 2016 was selected in this study regardless finance or real estate investment and trust (REIT's). The purpose of the generalisation because to have a concrete and standardization data represent main sector of each companies listed under Bursa Malaysia Securities Berhad. As mentioned, through Bursa Announcements(s) Outcome of the Meeting, all listed companies will disclose the overall total voting share of the resolution either number of shareholder's vote, percentage carried or rejected and total number of voting resolution at the general meeting. As required by the Bursa Malaysia Listing Requirements, the Outcome of the Meeting must be disclosing soonest possible after the meeting was held in Bursa Malaysia website and corporate website. Moreover, certain companies also recorded the overall total voting share of each resolution and include under minute of AGM.

\subsection{Data Collection}

Data collection for the shareholder's activism in this paper such as number resolution of the AGM and number of dissatisfaction vote or against the resolution were hand collected by the authors. To ensure the consistency and factual data, each of the Outcome of the Meeting were downloaded, analysed and recoded into the SPSS software. Besides that, the number of shareholding were cross check based on the company's annual report. To avoid bias in the data collection, the Outcome of the Meeting were supervised and cross checked by the third parties.

Meanwhile, prior to the adoption of Companies Act 2016, the financial year ended December 31, 2016 was chose for this study to examine the level of shareholder's activism among Malaysia listed companies. Due to the translation period, most of the listed companies only publish minimum requirements as stipulated by the Bursa Malaysia website. Therefore, using one-year observation, this paper critically evaluates the level of shareholder's activism (from the person and the corporation) through the exercise of voting right and attendance of the annual general meeting.

\subsection{Research Framework}

The sample of this paper comprised on dependent variable, DISCLOSURE that indicated through the shareholder's activism. The DISCLOSURE of the paper based on the listed of companies been 
monitored by MSWG. The primary reason of using this technique because the MSWG have its representative to attend the selected AGM meeting for the sake of minority shareholders. Prior studies show that the companies with MSWG monitored tend to produce a shareholder's activism from the voting power, frequent question and answer or attendance of the general meeting. Thus, using the dichotomous score, if there are companies monitored by MSWG, "1" will be assigned and "0" for otherwise.

To compare the independent variables, comprise the total resolution for each agenda, RESO and number of dissatisfaction vote or against the resolution, DISSENT. Total resolution of each AGM, RESO indicated the overall agenda discuss at the general meeting. As mentioned, during the general meeting, the agenda were tabled before put for the voting process near end of the general meeting. Hence, each of the resolution represent different voting result mostly reported in number of shareholding and voting percentage. Thus for this paper, the RESO can be measured based on the number of resolution tabled at the general meeting. It was assumed that the more resolution tabled at the general meeting indicate the seriousness of the meeting discussion.

Secondly, the number of dissatisfaction vote or against the resolution, DISSENT were presented based on the number of voting share against by the shareholders. Even though the against vote unable to influence the result of the agenda, however, once there existed the dissatisfaction of the voting share, there clearly shareholder's activism appeared at the meeting. Differ from the RESO, DISSENT can measure based on the percentage voting against of the resolution. Regardless how many percentages of against, this paper will have recorded, analysed and examine the movement of shareholder's activism.

Both of the independent variables can be shown in scale analysis. Same with the RESO, both independents variables data can be collected from the Outcome of the Meeting from Bursa Malaysia announcements.

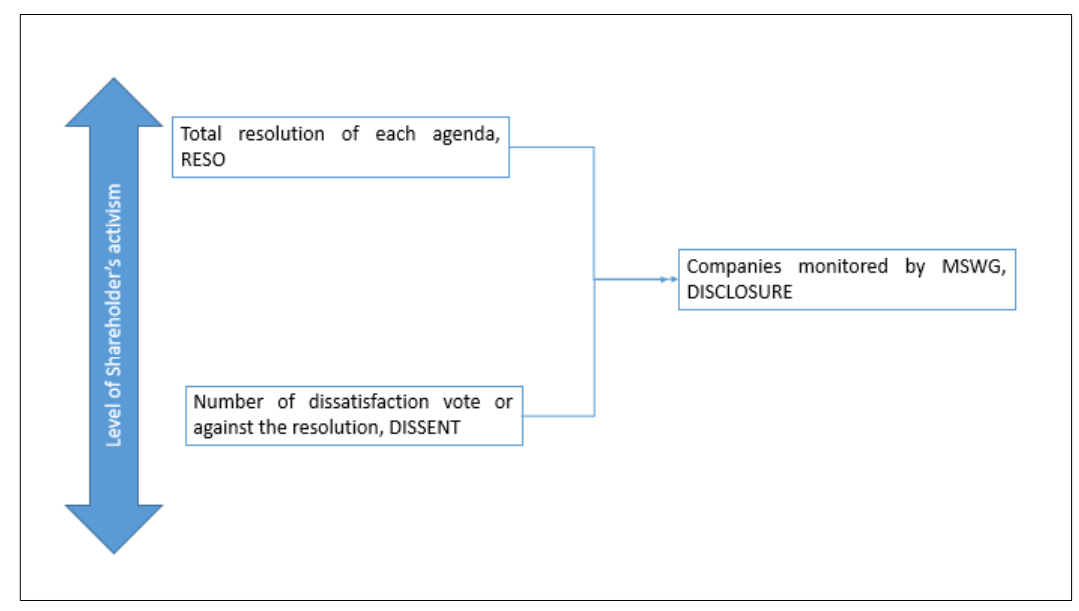

Fig. 1. Framework on the relationship between the dependent variable and independent variable(s) of the paper

The DISCLOSURE was extracted based on the companies monitored by MSWG during 2016/2017. The data collected from MSWG website and based on Malaysia-ASEAN Corporate Governance Scorecard report published annually by the MSWG [19]. As explained, both RESO and DISSENT information extracted from Outcome of the Meeting disclose by Bursa Malaysia website. Therefore, the percentage of voting exercise by the shareholders will be counted, re-calculated and examined for this studies. The level of shareholder's activism appears once the level of aggressiveness of the 
shareholders in the voting power especially against the resolution and frequency questions and answers on certain agenda lead to the more detailed of the data analysis.

\section{Data Analysis \\ 4.1 Descriptive Statistics}

In particular, Table 1 presents the mean, standard deviation, skewness and kurtosis of the variables for the study. As reflected in the Table, the dependent variable, DISCLOSURE have minimum 0 and maximum 1 and overall mean is 0.70 with a standard deviation of 0.459 . Meanwhile, the RESO shows that minimum number of agenda for the AGM mostly 1 and maximum is 17 resolutions. The mean and standard deviation consist of 8.8098 and 2.6942 respectively. The companies with below four agenda at the general meeting mostly from REITs companies such as Al-Aqar Heathcare REIT, AlSalam REIT, Amanahraya REIT, Axis Real Estate Investment Trust, Capitaland Malaysia Mall Trust, Pavilion REIT, Hektar REIT, MRCB-Quill REIT, Tower Real Estate Investment Trust Unit and UOA Real Estate Investment Trust REIT which is the agenda of the meeting slightly different from general AGM meeting under Section 143 of the Act (1). In term of DISSENT, the minimum is 0 and maximum is 9 with mean of 0.4674 and standard deviation of 1.1730 respectively. It shows that almost all listed companies agreed with the agenda table at the meeting.

In term of the relibaility and validity of the data, both skewness and kurtosis values provide range values within -2 to +2 indicated that the distribution is at the peakerd [20];[21] thus considered fairly normal distributed.

Table 1

Descriptive Statistics of the paper

\begin{tabular}{|c|c|c|c|c|c|c|c|c|}
\hline & \multirow{2}{*}{$\begin{array}{c}\text { Minimum } \\
\text { Stat }\end{array}$} & \multirow{2}{*}{$\begin{array}{c}\text { Maximum } \\
\text { Stat }\end{array}$} & \multirow{2}{*}{$\begin{array}{l}\text { Mean } \\
\text { Stat }\end{array}$} & \multirow{2}{*}{$\begin{array}{c}\text { Std. } \\
\text { Deviation } \\
\text { Stat }\end{array}$} & \multicolumn{2}{|c|}{ Skewness } & \multicolumn{2}{|c|}{ Kurtosis } \\
\hline & & & & & Stat & SE & Stat & SE \\
\hline DISCLOSURE & 0.00 & 0.001 & 0.7000 & 0.459 & -0.876 & 0.150 & -1.242 & 0.299 \\
\hline RESO & 1.00 & 17.00 & 8.8098 & 2.6942 & 0.084 & 0.179 & 1.008 & 0.356 \\
\hline DISSENT & 0.00 & 9.00 & 0.4674 & 1.1730 & 4.053 & 0.179 & 20.736 & 0.356 \\
\hline
\end{tabular}

Table 2 shows the overall agenda discuss at the general meeting, RESO of this paper. Generally, there is range between 1 to 17 each agenda table at the AGM. The higher number of agenda is between 7 to 9 by 27 number respectively. Meanwhile, in contrast, the least agenda is 14 and 17 number respectively. The Figure 2 shows the composition of each agenda discussion at the general meeting. From this result, it indicates that most of the shareholders are aware of their role and had gradually becoming more active in exercising their rights, especially during the voting process.

Table 2

Frequency Statistics of the paper

\begin{tabular}{|c|c|c|c|c|c|c|c|}
\hline RESO & Frequency & Percent & $\begin{array}{r}\text { Cumulative } \\
\text { Percent }\end{array}$ & RESO & Frequency & Percent & $\begin{array}{r}\text { Cumulative } \\
\text { Percent }\end{array}$ \\
\hline 1.00 & 2 & 1.1 & 1.1 & 11.00 & 12 & 6.5 & 85.3 \\
\hline 2.00 & 3 & 1.6 & 2.7 & 12.00 & 14 & 7.6 & 92.9 \\
\hline 4.00 & 3 & 1.6 & 4.3 & 13.00 & 5 & 2.7 & 95.7 \\
\hline 5.00 & 7 & 3.8 & 8.2 & 14.00 & 1 & 0.5 & 96.2 \\
\hline 6.00 & 13 & 7.1 & 15.2 & 15.00 & 4 & 2.2 & 98.4 \\
\hline 7.00 & 27 & 14.7 & 29.9 & 16.00 & 2 & 1.1 & 99.5 \\
\hline 8.00 & 31 & 16.8 & 46.7 & 17.00 & 1 & 0.5 & 100.0 \\
\hline 9.00 & 27 & 14.7 & 61.4 & Total & 184 & 100.0 & \\
\hline 10.00 & 32 & 17.4 & 78.8 & & & & \\
\hline
\end{tabular}




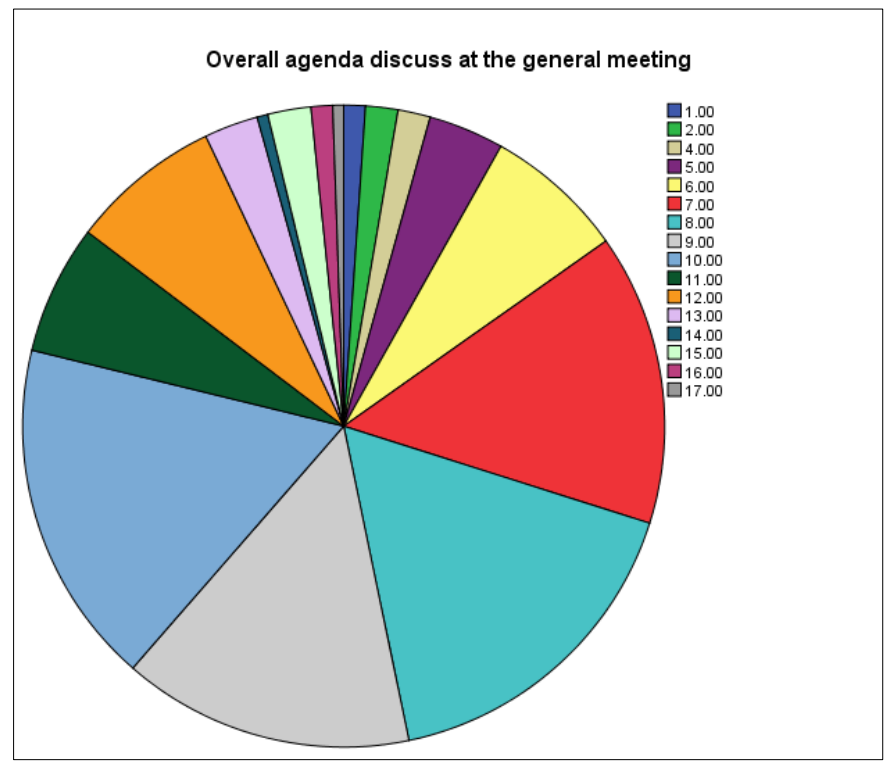

Fig. 2. Overall agenda discuss at the general meeting, RESO

Table 3

Frequency Statistics of the paper

\begin{tabular}{lccc}
\hline DISSENT & Frequency & Percent & Cumulative Percent \\
\hline 0.00 & 140 & 76.1 & 76.1 \\
1.00 & 26 & 14.1 & 90.2 \\
2.00 & 9 & 4.9 & 95.1 \\
3.00 & 4 & 2.2 & 97.3 \\
4.00 & 1 & .5 & 97.8 \\
5.00 & 1 & .5 & 98.4 \\
6.00 & 2 & 1.1 & 99.5 \\
9.00 & 1 & .5 & 100.0 \\
Total & $\mathbf{1 8 4}$ & $\mathbf{1 0 0 . 0}$ & \\
\hline
\end{tabular}

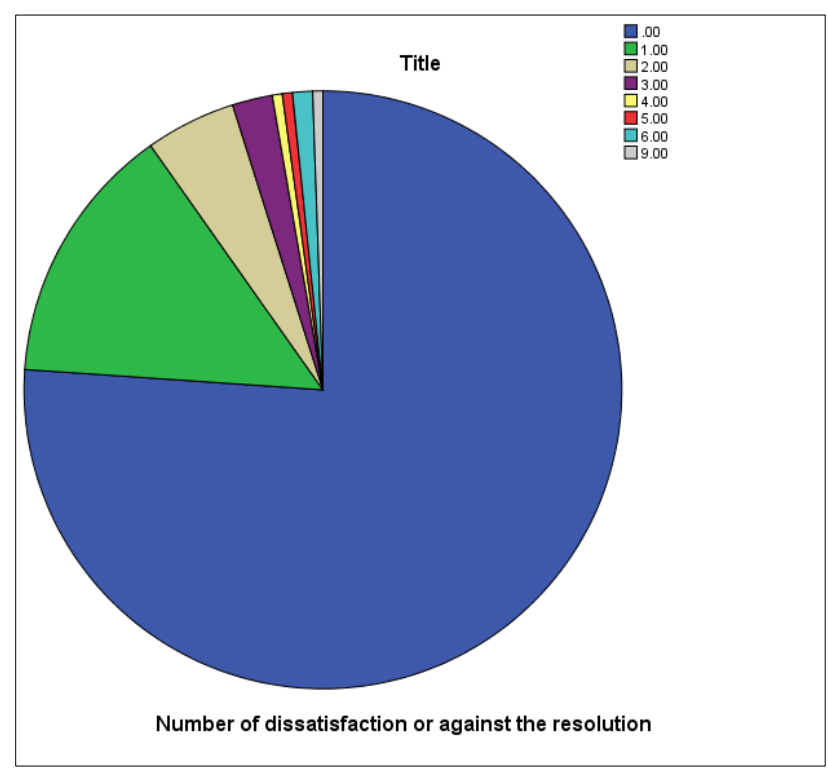

Fig. 3. Number of dissatisfaction or against the resolution 
Meanwhile, Table 3 reported the number of dissatisfaction or against the resolution of the paper. Out of 184 sample, most of the agenda fully agreed by the shareholders with 76 percent vote for the resolution. However, in term of the shareholder's dissatisfaction, 26 companies vote against with at least one resolution followed with 9 companies against the resolution with two resolutions. The composition of the number of dissatisfaction or against the resolution was shows under Figure 3.

Interestingly, with the implementation of the newly Companies Act 2016, most of the Malaysia firms had shifted to e-voting during the general meeting in aligning with the advance technology which promotes efficient and faster voting result. In terms of the existence of shareholder's activism, the MSWG was established mainly to protect the minority shareholders especially in exercising their voting right. In fact, MSWG has also acted as an intermediator between the regulatory bodies and the companies to ensure the shareholders are able to speak and exercise their voting power even though with limited capacity due to minority ownership.

Besides that, there are several categories of shareholders in activism namely the individual, corporation or government linked companies (GLCs). Majority of the ownership in Malaysian listed companies whether Large companies or Non-Large companies are dominated by the individual shareholders who topped the 30 largest shareholders. Meanwhile, a number of the companies' ownership are also dominated by foreign investors as well as a private entities and Government Linked Companies (GLCs) such as Petronas Gas Malaysia Berhad, Telekom Malaysia Berhad, Tenaga Nasional Berhad or Felda Global Venture Holdings Berhad.

\subsection{Correlations Analysis}

Based on Table 4, the relationship between companies monitored by MSWG indicated level of shareholder's activism (DISCLOSURE) and the number of agenda at the general meeting (RESO) with the number of dissatisfaction or against the resolution (DISSENT) was tested using Pearson Correlations Coefficients. The analysis was performed after there was no violation of the assumptions of normality, linearity, and homoscedasticity between each item. From the analysis, it shows that was a strong positive correlation between the DISCLOSURE and RESO with 0.199 significant at 0.01 level. The correlation analysis confirms the evidenced of relationship between level of shareholder's activism (based on the agenda of the resolution) and shareholder's involvement at the general meeting.

Table 4

Correlations Statistics of the paper

\begin{tabular}{llrrr}
\multicolumn{5}{c}{ Correlations } \\
\hline & DISCLOSURE & RESO & DISSENT \\
\hline \multirow{2}{*}{ DISCLOSURE } & Pearson Correlation & 1 & & \\
\multirow{2}{*}{ RESO } & Sig. (2-tailed) & & & \\
& Pearson Correlation & -0.002 & & \\
DISSENT & Sig. (2-tailed) & 0.972 & & 1 \\
& Pearson Correlation & 0.071 & $0.199^{* *}$ & \\
\hline
\end{tabular}

**. Correlation is significant at the 0.01 level (2-tailed). 


\subsection{Multiple Regression Analysis}

A linear multiple regression analysis was used for this paper. The linear multiple regression used to explain how much the variance in the disclosure information sample is able to explain as a group. Based on Table 5, a standard linear multiple regressions used to predict the number of agenda of the resolution, RESO and the number of dissatisfaction or against the resolution, DISSENT with the level of shareholder's activism based on companies monitored by MSWG, DISCLOSURE. The total variance explained by the model was 0.006 which is relatively small. In the Coefficients model, both two variables were considered not significant as the RESO recorded a lower value (beta $=-0,024)$ and DISSENT also recorded a lower value (beta $=0.077$ ) (See Appendix for further information).

\section{Table 5}

Multiple Regression Analysis of the paper

Coefficients ${ }^{\mathrm{a}}$

\begin{tabular}{|c|c|c|c|c|c|c|c|c|}
\hline \multirow{2}{*}{\multicolumn{2}{|c|}{ Model }} & \multicolumn{2}{|c|}{ Unstandardized Coefficients } & \multirow{2}{*}{$\begin{array}{l}\begin{array}{l}\text { Standardized } \\
\text { Coefficients }\end{array} \\
\text { Beta }\end{array}$} & \multirow[t]{2}{*}{$\mathbf{t}$} & \multirow[t]{2}{*}{ Sig. } & \multicolumn{2}{|c|}{ Collinearity Statistics } \\
\hline & & $\mathrm{B}$ & Std. Error & & & & Tolerance & VIF \\
\hline & (Constant) & 0.721 & 0.096 & & 7.498 & 0.000 & & \\
\hline \multirow[t]{2}{*}{1} & RESO & -0.004 & 0.011 & -0.024 & -0.365 & 0.715 & 0.924 & 1.083 \\
\hline & DISSENT & 0.031 & 0.026 & 0.077 & 1.199 & 0.232 & 0.924 & 1.083 \\
\hline
\end{tabular}

a. Dependent Variable: DISCLOSURE

Collinearity Diagnostics ${ }^{\mathrm{a}}$

\begin{tabular}{lllrrrr}
\hline Model & Dimension & Eigenvalue & Condition Index & \multicolumn{2}{c}{ Variance Proportions } \\
& & & & (Constant) & RESO & DISSENT \\
\hline & 1 & 2.187 & 1.000 & 0.02 & 0.02 & 0.06 \\
1 & 2 & 0.769 & 1.686 & 0.01 & 0.01 & 0.88 \\
& 3 & 0.043 & 7.112 & 0.97 & 0.98 & 0.05 \\
\hline
\end{tabular}

a. Dependent Variable: DISCLOSURE

The result of the paper found that by using sample of the firms that disclosed the extensive information as suggested by MSWG, the experiment of the analysis shows that the level of shareholder's activism indicated through the shareholder's participation (total resolution on general meetings) and shareholders voting (percentage vote against the resolution) does not bring much impact towards the level of shareholder's activism among the firms monitored by the MSWG. Hence, from this paper, additional variables can be included in order to widen the scope of the level of shareholder's activism among Malaysia listed companies.

\section{Discussion and Conclusion}

Despite the findings indicated that the companies monitored by MSWG did not bring much impact toward number of agenda of the resolution and the number of dissatisfaction or against the resolution, MSWG keep monitored the companies over the years. One of the possible reason due to the importance of shareholder's activism especially involved the minority shareholders. Even though 
the result shows no significant impact of the number of agenda of the resolution and the number of dissatisfaction or against the resolution to the level of shareholder's activism among Malaysian listed companies, this paper open for more discussion about the role played by the shareholders. As stressed by Baloria studies, the shareholder's activism most likely occur once the voluntary disclosure information regarding the companies [9].

\subsection{Contribution}

This paper highlighted the level of shareholder's activism measured based on the companies monitored by MSWG. In international level such as European countries, the watchdog group play an important effect on the shareholder's decision making especially among minority shareholders. First, this study evaluates the shareholders' activism based on the number of agenda of the resolution and the number of dissatisfaction or against the resolution. This is because from the practitioner viewpoint, the shareholders aware once lots of agenda discuss during the general meeting. Besides that, it also affects the company's performance and investors investment once the wrong decision had been made. Thus, can lead toward aggressive shareholders such as scenario of Sapura Energy's Berhad. Among the contribution of this paper such as firstly, its shows that more detailed analysis should be conducted in determine the level of shareholders' activism. In fact, the control variable may impact the relationship between the variables of the studies which is not covered by the paper.

Secondly, if the level of shareholders in Malaysia relatively low, what is the purpose of the establishment MSWG or Institutional Investors of Malaysia (IIAM). Over the decades, the literature shows that decision making frequently dominated by the controlled shareholders even though minority shareholders also has a right to exercise voting right and attend the general meeting. Thus, this paper focus on the number of agenda and against resolution as an indicator toward level of shareholders' activism.

Lastly, Malaysia comprised of multi-cultural and multi-ethnicity and among the leading example of a good governance. The introduction of the Securities Commission of Blueprint (2011), revised Malaysia Code on Corporate Governance (2000, 2007, 2012 \& 2017), Bursa Malaysia Governance Guide (2017) and compulsory of the Corporate Governance Report making Malaysia toward a better governance system. Related to the shareholders' activism, all the guidelines helping them to exercise their power and right regardless controlling or minority shareholders. Besides that, shareholders in Malaysia slowly change from passive to aggressive shareholders [16].

\subsection{Limitation}

From the result of the studies, it reveals that more analysis and data collection on shareholder's activism need to be examined and explore. Even though few studies had confirmed that dissatisfaction of the shareholders lead toward activism however the scenario different for Malaysia perspective. As such, the studies required extensive research on the determinants of level shareholder's activism. Secondly, the paper also required in-depth observation on the main factors that lead toward certain companies monitored by MSWG compared to non-monitored. Lastly, the paper should be observed the shareholder's activism either an individual or the corporation and through perspective of local or foreign investors.

\subsection{Future studies}

It is highly recommended for more extensive studies on the shareholder's activism among 
Malaysian listed companies. The involvement of the controlling variables may impact the relationship of this paper. Thus controlling variables can be look through financial and non-financial aspects. In addition, this studies can be improving by including the prior and post adoption of the Companies Act 2016. The policy maker should exercise their roles to promote active shareholders, especially during the general meeting. Besides that, policy makers should encourage the shareholders to understand and play their role efficiently toward a best practice. As the result show that the level of shareholders' awareness toward shareholders' participation and voting during the general meetings remain low in Malaysia's perspective. In the nutshell, "stakeholders" consist of the ownership of the company, board of directors, investors and suppliers, the stakeholders must fully exercise their roles to ensure that the power not supress by the dominant party and in accordance with the law. Stakeholders function not merely to fit the company structure but they also importance for the company profit maximisation.

The paper aims to highlight the level of the shareholder's activism in Malaysia and how it is associated with the voluntary disclosure information among companies monitored by the MSWG for the year 2016. Even though, the findings of the study did not provide any association between number of agenda of the resolution and the number of dissatisfaction or against the resolution toward level of shareholders' activism, through companies monitored by MSWG, this paper managed to enlighten the importance of shareholder activism that empowers shareholders to exercise their power and rights, to speak during the general meeting and influence the decision making. To this end, to supplement the extant studies in Malaysia on shareholder activism, future researchers now need to emphasise on the factors that contribute to an effective and successful shareholder activism among listed companies in Malaysia.

\section{References}

[1] Companies Act 2016. Law of Malaysia. Percetakan Nasional Malaysia Berhad. (2016).

[2] Berhad, Bursa Malaysia. "Listing Requirements." Bursa Malaysia, Kuala Lumpur (2019).

[3] Van der Elst, Christoph. "Answering the say for no pay." Innovations in corporate governance-global perspectives. Edward Elgar, Cheltenham (2017): 151-190.

https://doi.org/10.4337/9781786432858.00016

[4] Salim, Mohammad Rizal, and Yee Shyun Ong. "The Law on Shareholders' Meetings in Malaysia." In This material was first published by Thomson Reuters (Professional) UK Limited in Mohammad Rizal Salim, "The Law on Shareholders' Meetings in Malaysia"[2009] ICCLR, vol. 20, no. 12, p. 436. 2009.

[5] Dictionary, Oxford English. "Oxford: Oxford university press." (1989).

[6] Aggarwal, Reena, Isil Erel, Miguel Ferreira, and Pedro Matos. "Does governance travel around the world? Evidence from institutional investors." Journal of Financial Economics 100, no. 1 (2011): 154-181.

https://doi.org/10.1016/i.jfineco.2010.10.018

[6] Konrath, Robert, Christian Klein, and Andreas Schröder. "PSP and PIV investigations on the VFE-2 configuration in sub-and transonic flow." Aerospace Science and Technology 24, no. 1 (2013): 22-31.

https://doi.org/10.1016/i.ast.2012.09.003

[7] Hartzell, Jay C., and Laura T. Starks. "Institutional investors and executive compensation." The Journal of Finance 58, no. 6 (2003): 2351-2374.

https://doi.org/10.1046/j.1540-6261.2003.00608.x

[8] Akmal Musa, Maizatul, and Shahril Eashak Ismail. "Shareholder Activism, Institutional Shareholders and Agency Problems in Malaysia." (2016).

[9] Baloria, Vishal P., Kenneth J. Klassen, and Christine I. Wiedman. "Shareholder activism and voluntary disclosure initiation: The case of political spending." Contemporary Accounting Research 36, no. 2 (2019): 904-933. https://doi.org/10.1111/1911-3846.12457

[10] Goranova, Maria, and Lori Verstegen Ryan. "Shareholder activism: A multidisciplinary review." Journal of Management 40, no. 5 (2014): 1230-1268. https://doi.org/10.1177/0149206313515519

[11] Gillan, Stuart L., and Laura T. Starks. "Corporate governance proposals and shareholder activism: The role of institutional investors." Journal of Financial Economics 57, no. 2 (2000): 275-305. 
https://doi.org/10.1016/50304-405X(00)00058-1

[12] Hartzell, Jay C., and Laura T. Starks. "Institutional investors and executive compensation." The Journal of Finance 58, no. 6 (2003): 2351-2374.

https://doi.org/10.1046/i.1540-6261.2003.00608.x

[13] De Jong, Abe, Gerard Mertens, and Peter Roosenboom. "Shareholders' voting at general meetings: Evidence from the Netherlands." Journal of Management \& Governance 10, no. 4 (2006): 353-380. https://doi.org/10.1007/s10997-006-9006-1

[14] Mallin, Chris. "Institutional investors: the vote as a tool of governance." Journal of Management \& Governance 16, no. 2 (2012): 177-196.

https://doi.org/10.1007/s10997-010-9137-2

[15] Othman, Sarina, and William G. Borges. "Shareholder Activism in Malaysia: Exploring a Missing Parameter." In Proceedings of the 1st AAGBS International Conference on Business Management 2014 (AiCoBM 2014), pp. $367-$ 378. Springer, Singapore, 2016. https://doi.org/10.1007/978-981-287-426-9 32

[16] Jayaseelan, Risen. "MSWG: Singapore Proposals Relevant to Malaysia." The Star 15 (2011).

[17] Jansson, Andreas. "No Exit!: The Logic of Defensive Shareholder Activism." Corporate Board: Role, Duties \& Composition 10, no. 2 (2014): 16-31.

https://doi.org/10.22495/cbv10i2art2

[18] Poulsen, Thomas, Therese Strand, and Steen Thomsen. "Voting power and shareholder activism: A study of Swedish shareholder meetings." Corporate Governance: An International Review 18, no. 4 (2010): 329-343. https://doi.org/10.1111/i.1467-8683.2010.00811.x

[19] Dy, Michelle. "Capital Market Integration in the EU and ASEAN." Available at SSRN 2956160 (2017). https://doi.org/10.2139/ssrn.2956160

[20] Hair Jr, Joseph F., Mary Wolfinbarger, Arthur H. Money, Phillip Samouel, and Michael J. Page. Essentials of Business Research Methods. Routledge, 2015. https://doi.org/10.4324/9781315704562

[21] Sekaran, Uma, and Roger Bougie. Research methods for business: A Skill Building Approach. John Wiley \& Sons, 2016.

[22] Louie, J., Ahmed, K., \& Ji, X. D. (2019). Voluntary disclosures practices of family firms in Australia. Accounting Research Journal. https://doi.org/10.1108/ARJ-04-2016-0042

[23] Ameer, R., \& Rahman, R. A. (2009). The Impact of Minority Shareholder Watchdog Group Activism On The Performance Of Targeted Firms In Malaysia. Asian Academy of Management Journal of Accounting \& Finance, 5(1).

[24] Jensen, M. C., \& Meckling, W. (1976). H.(1976). Theory of the firm: managerial behavior, agency costs and ownership structure En: Journal of Finance Economics, 3. https://doi.org/10.1016/0304-405X(76)90026-X

[25] Abd Mutalib, H., Jamil, M., Zuriana, C., \& Wan Hussin, W. N. (2016). Understanding the share ownership of institutional investors in Malaysia. Australian Journal of Basic and Applied Sciences, 10(11 s), 176-184.

[26] Satkunasingam, E., \& Shanmugam, B. (2006). The consequences of culture on shareholder activism in Malaysia. Journal of Applied Management Accounting Research, 4(1), 45.

\section{Appendix}

\section{Multiple Regression Analysis}

\section{Table 5}

Multiple Regression Analysis of the paper

Model Summary

\begin{tabular}{|l|r|r|r|r|}
\hline Model & R & R Square & \multicolumn{1}{|c|}{$\begin{array}{c}\text { Adjusted R } \\
\text { Square }\end{array}$} & $\begin{array}{l}\text { Std. Error of the } \\
\text { Estimate }\end{array}$ \\
\hline 1 & $.074^{\mathrm{a}}$ & .006 & -.002 & .460 \\
\hline
\end{tabular}

a. Predictors: (Constant), DISSENT, RESO 
ANOVA $^{\mathrm{a}}$

\begin{tabular}{|rl|r|r|r|r|r|}
\hline \multicolumn{2}{|l|}{} & Sum of Squares & df & Mean Square & F & Sig. \\
\hline \multirow{2}{*}{1} & Regression & .304 & 2 & .152 & .719 & $.488^{\mathrm{b}}$ \\
& Residual & 54.966 & 260 & .211 & & \\
& Total & 55.270 & 262 & & & \\
\end{tabular}

a. Dependent Variable: DISCLOSURE

b. Predictors: (Constant), DISSENT, RESO 